1. Assistant Professor, Department of Textiles \& Clothing, Government College of Home Economics, Gulberg, Lahore

2. Assistant Prof and

HOD of Biostatistics

Gulab Devi PGMI Lahore.

3. Principal,

Govt. College of Home Economics, Gulberg, Lahore.

4. Director General

PCSIR Laboratories Complex, Lahore.

5. Professor of Orthopedics, Head of Orthopedics Department, King Edward Medical University, Lahore.

6. Lecturer Home economics, Lahore college women university, Jail Road, Lahore.

Correspondence Address: Dr. Farzana Kishwar Assistant Professor Department of Textile \& Clothing, Government College of

Home Economics, Gulberg, Lahore

f_kishwar@yahoo.ca

\section{COMPARISON OF PORE SIZE ANALYSIS OF EXISTING AND EXPERIMENTAL SURGICAL GOWNS}

\author{
Dr. Farzana Kishwar ${ }^{1}$, Asif Hanif ${ }^{2}$, Dr. Samia Kalsoom ${ }^{3}$, Dr. Shahzad Alam ${ }^{4}$ Dr. Mohammad Tariq Sohail ${ }^{5}$, \\ Ms. Mehreen ljaz $^{6}$
}

ABSTRACT... Majority of the public and private sector hospitals are using reusable gowns and scrubs whereas only a few hospitals are using disposable ones. Protection during surgery is very important both for the patient as well as for the surgeon. The reasons are not only hygienic but also creating a barrier so that the bacteria and the viruses do not transfer from patient to doctor and vice versa. The surgical gowns have been in use for many decades. With the advancements in the field of manufacturing (weaving and finishing), the quality of gowns has been improving over the period of time. In Pakistan, there is no awareness yet regarding the construction of surgical apparels viz. surgical gowns and scrubs so no standards are being followed as such during the manufacturing (weaving \& finishing) of surgical apparels. For effective barrier function of surgical gowns and scrubs, it is necessary for them to comply with certain standards in terms of physical characteristics viz. mass per unit area, number of threads per unit length, tensile strength etc. The idea behind this study was to evaluate the physical characteristics of surgical gowns and scrubs currently being used in different public sector hospitals of Lahore. Objectives: (1) To evaluate the pore size of existing and experimental surgical gowns being used in different hospitals of Lahore. (2) To compare the pore size analysis of existing surgical gowns with experimental surgical gowns. Study Design: Experimental study design was used. Duration: January 2014- April 2014. Materials and Methods: Samples of fabric used for making surgical gowns and scrubs were collected from different hospitals of Lahore and evaluated for pore size with the help of optic microscope. For experimental gowns the fabric was developed according to the international standards. Pore size of surgical gowns was measured with the help of scanning electron microscope. Results: The results showed large pores in existing surgical gown. No length or width wise pores in the experimental surgical gowns fabric except there are tiny holes of 0.5 after 20 launderings. The existing reusable surgical gowns did not offer any resistance against bacterial penetration because of large pores. Conclusions: The fabric used for the existing surgical gowns was not up to the mark and did show large pores under microscope. The experimental surgical gown showed no pores in the fabric structure when subjected to scanning electron microscope. The functional ability of resistance against bacterial penetration of the surgical gowns is important because the risk of SSI. If the patient develops SSI weather it is grades 1,2 or 3 , the cost is significant. The cost effectiveness of the existing reusable surgical gowns becomes insignificant as none of the existing surgical gowns offer any resistance against bacterial penetration and the risk of SSI with subsequent treatment cost. Necessary guidelines can be formulated and proposed to the concerned departments of various hospitals, in the light of which they can design some specifications and select appropriate materials for surgical apparels in future.

Key words: $\quad$ Pore size, surgical gowns,

Article Citation: Kishwar F, Hanif A, Kalsoom S, Alam S, Sohail MT, ljaz M. Comparison of pore size analysis of existing and experimental surgical gowns. Professional Med J 2014;21(4): 804-809.
Article received on:

26/06/2014

Accepted for Publication:

$17 / 07 / 2014$

Received after proof reading:

$16 / 08 / 2014$ potential of textiles is being utilized to provide the resistance not only against cold or rain but also against micro-organisms and impact forces etc. with the increasing awareness regarding the 
transmittable infections, the operation room textiles are major focus in this area of research. In 2003, Aibibu, Lehmann and Offerman ${ }^{1}$ studied the pore structure of woven fabrics existing in the market with different weaving types, viewing the fabric cross-section. Their study was designed to assess the cloth parameters on fabric compactness. Laundering decreases the prevention of the diffusion of bacteria through the fabrics. Prior studies have concentrated on the assessment of the fabric's barrier property and ease of health care workers. It is important to identify the effects of the textile's constructional parameters such as fabric density (fabric construction), the linear density of the filament yarns, and impact of washing on the pore size of the operating room textiles. Leonas $(1998)^{2}$ found out that washing opens the pore of the cloth to help the microorganism pass through the fabric. The blockade function depends on the fabric construction and the number and size of the pores. These pores are present between the yarns and between the fibers. These hole or space assemblies are differentiated using visual pictures of fabrics cross-sections ${ }^{1}$.

\section{Pore Size of Surgical Gowns}

Fabrics with smaller pore size are considered to have better barrier efficacy. As a principle, the hole of the cloth should be smaller than the size of micro-organism or its transporter. For example, in case of blood borne bacterial infections pore of the cloth must be lesser than the size of the microorganisms and the transporter, if carriers like dust or shed skin cells are considered important ${ }^{3}$. Many studies have been conducted on the relation of pore size $e^{1,2}$. Non-woven material showed higher barrier efficacy ${ }^{3}$.

The researchers have made a conclusion that fabrics show signs of bimodal distribution of pores. This suggests the pore distribution not only in interstices of yarns but also within yarns. In addition to that, the surgical gowns should not have any holes, punctures and slits $^{4}$.

Surgical gown fabric should be defiant to prick and rip to stop microbial pollution. AST discussed that surgical gowns should be helpful as a barrier for blood, body liquids, intra operatively patient body fluids and irrigating solutions. These make a contact with gowns and gowns should be water and fluid defiant to prevent strike-through contamination from microbes. It is further emphasized by AST that reusable woven gown fabric must have the same line of defense as single-use non-woven disposable gown fabrics have. The protective surgical apparels can do better if the relationship between barriers and carriers, i.e., its hydrodynamic, is known ${ }^{4}$. The pore geometry of the fabric has a major effect on its air permeability ${ }^{5}$. A variety of studies have demonstrated the significance of using sterilized hospital textiles for less infectious operating ${ }^{6,7}$. With the progress in pore science of textiles it became very significant to balance the blockade and comfort properties as well as maintaining the required standards $s^{8,9}$.

\section{Pore Size Analysis of Surgical Gown Fabric (porosity)}

Macro-Examination was performed by using Optic Microscope (Olympus, Model: SZX7) and Pore size measured by Micrometer (model no. S78). Fabric samples were cut according to prescribed size and observed under microscope. The images were taken at a magnification of 56x, the images were saved and developed on photographic paper. The pore size was observed both width and length wise. Then pore size was measured with the help of micrometer (graticules PYSER-SGI Ltd. Serial no. 02B00421 model no. S78). Every sample was measured at three different places for both width and length of pores. The average width and length was calculated.

\section{Pore size analysis of surgical gown fabric} (porosity)

The computer-assisted SEM/EDS were used to perform pore size analysis test. SEM consumes vacuum conditions and uses electrons to form an image, special preparations must be done to the sample. Because the SEM vacuum conditions and uses electrons to form an image, all water must be removed from the samples because the water would vaporize in the vacuum. The sample is 
placed in a small chamber that is at a vacuum. We can see the image on computer screen. The sample was scanned at different locations on fabric.

\section{MATERIALS AND METHODS}

\section{Study Design}

Experimental study design was used.

\section{Period}

January 2014- April 2014.

\section{Samples}

Samples of fabric used for making surgical gowns and scrubs were collected from different hospitals of Lahore and evaluated for pore size with the help of optic microscope. For experimental gowns the fabric was developed according to the international standards. Pore size of surgical gowns was measured with the help of scanning electron microscope.

\section{Data analysis}

All data was entered in SPSS 20 version and was analyzed with same software. Mean \pm S.D was used for quantitative data. Kruskal-Wallis $\mathrm{H}$ test was used to compare the quantitative data in all three groups. P-value $=0.05$ was taken as significant.

\section{RESULTS}

Pore Width (um) of Existing surgical gowns at different laundry intervals

Porosity of the fabric used for the surgical gown is important not only it makes the fabric comfortable and aerated but it allows pathogens and other bacteria to pass through the fabric. The size of the pore has to be optimum both in its length, width and distribution. Porosity is expected to remain optimal during the cycle or use in laundry.

\begin{tabular}{|c|c|c|c|c|}
\hline & Groups of Clothes & $\mathbf{n}$ & Mean & SD \\
\hline Pore Width um (New Gowns) & $\begin{array}{l}\text { Group A } \\
\text { Group B } \\
\text { Group C }\end{array}$ & $\begin{array}{l}5 \\
5 \\
5\end{array}$ & $\begin{array}{l}118.96 \\
193.88 \\
163.50\end{array}$ & $\begin{array}{c}35.75 \\
192.66 \\
70.94\end{array}$ \\
\hline \multicolumn{2}{|l|}{ Total } & 15 & 158.78 & 115.85 \\
\hline Pore Width um (5-laundering) & $\begin{array}{l}\text { Group A } \\
\text { Group B } \\
\text { Group C }\end{array}$ & $\begin{array}{l}5 \\
5 \\
5\end{array}$ & $\begin{array}{l}129.28 \\
226.40 \\
243.50\end{array}$ & $\begin{array}{c}38.22 \\
201.72 \\
141.26\end{array}$ \\
\hline \multicolumn{2}{|l|}{ Total } & 15 & 199.72 & 143.02 \\
\hline Pore Width um (10-laundering) & $\begin{array}{l}\text { Group A } \\
\text { Group B } \\
\text { Group C }\end{array}$ & $\begin{array}{l}5 \\
5 \\
5\end{array}$ & $\begin{array}{l}229.50 \\
323.96 \\
312.06\end{array}$ & $\begin{array}{l}174.18 \\
231.72 \\
210.34\end{array}$ \\
\hline \multicolumn{2}{|l|}{ Total } & 15 & 288.50 & 196.32 \\
\hline Pore Width um (15-laundering) & $\begin{array}{l}\text { Group A } \\
\text { Group B } \\
\text { Group C }\end{array}$ & $\begin{array}{l}5 \\
5 \\
5\end{array}$ & $\begin{array}{l}246.02 \\
503.88 \\
342.18\end{array}$ & $\begin{array}{l}172.08 \\
341.11 \\
229.92\end{array}$ \\
\hline \multicolumn{2}{|l|}{ Total } & 15 & 364.02 & 262.56 \\
\hline Pore Width um (20-laundering) & $\begin{array}{l}\text { Group A } \\
\text { Group B } \\
\text { Group C }\end{array}$ & $\begin{array}{l}5 \\
5 \\
5\end{array}$ & $\begin{array}{l}252.92 \\
689.86 \\
420.14\end{array}$ & $\begin{array}{l}177.84 \\
445.95 \\
231.85\end{array}$ \\
\hline \multicolumn{2}{|l|}{ Total } & 15 & 454.30 & 340.49 \\
\hline
\end{tabular}

Table-I. Descriptive Statistics for Group wise Pore Width (um) Existing surgical gowns at Different Laundry Intervals 
The table indicates the mean pore width (um) at various laundering intervals among the three study groups. In Group A, the mean pore width was $118.96 \pm 35.75$ for new gown Laundering, $129.28 \pm 38.22$ at $5 \mathrm{th}$ Laundering, $229.50 \pm 174.18$ at 10 th Laundering, $246.02 \pm 172.08$ at $15^{\text {th }}$ Laundering and 252.92 \pm 177.84 at 20th Laundering. Similarly, in Group B, the mean values for width pore (um) were recorded as 193.88 $\pm 192.66,226.40 \pm 201.72$, $323.96 \pm 231.72, \quad 503.88 \pm 341.11$ and $689.86 \pm 445.95$ respectively, while, in Group C, the mean pore width (um)for these intervals were noted as $163.50 \pm 70.94,243.50 \pm 141.26$, $312.06 \pm 210.34, \quad 342.18 \pm 229.92$ and $420.14 \pm 231.85$ respectively. Clearly, with increased laundries, an increasing trend in pore width can be observed in all groups for average pore widths, which was also statistically significant i.e. $p$-value $=0.001$. Also, this increasing trend was same in all the three study groups as well. In figure 70 there is an increasing pore width trend can be seen in all study groups, and Group C showed the highest pore width value at 20th laundering interval, whereas, lowest pore widths were observed throughout in Group A. Statistically too, the mean increasing trend in pore widths among all three groups was same i.e. p-value $=0.157$.

The table shows average pore width (um) at different laundering intervals among the three study groups. The mean pore width in Group A was reported as $120.40 \pm 26.33$ for new gown, $127.76 \pm 24.75$ at 5 th Laundering, 137.96 \pm 17.23 at 10th Laundering, $151.24 \pm 30.21$ at 15 th Laundering and 165.22 \pm 37.03 at 20th Laundering. In Group B, on other hand, the mean values for width pore (um)were recorded as $111.94 \pm 40.45$, $155.22 \pm 64.44$, 332.64 $\pm 228.15,419.34 \pm 302.89$ and $550.60 \pm 285.54$ respectively, whereas, in Group C, the average pore width (um)for all intervals were noted as $160.74 \pm 96.84$, $225.76 \pm 189.59,257.52 \pm 173.61,314.40 \pm 182.38$ and $357.86 \pm 190.1$ respectively. Statistically, there

\begin{tabular}{|c|c|c|c|c|}
\hline & Groups of Clothes & $\mathbf{n}$ & Mean & SD \\
\hline Pore Width um (New Gowns) & $\begin{array}{l}\text { Group A } \\
\text { Group B } \\
\text { Group C }\end{array}$ & $\begin{array}{l}5 \\
5 \\
5\end{array}$ & $\begin{array}{l}120.40 \\
111.94 \\
160.74\end{array}$ & $\begin{array}{l}26.33 \\
40.45 \\
96.84\end{array}$ \\
\hline \multicolumn{2}{|l|}{ Total } & 15 & 131.02 & 61.89 \\
\hline Pore Width um (5-laundering) & $\begin{array}{l}\text { Group A } \\
\text { Group B } \\
\text { Group C }\end{array}$ & $\begin{array}{l}5 \\
5 \\
5\end{array}$ & $\begin{array}{l}127.76 \\
155.22 \\
225.76\end{array}$ & $\begin{array}{c}24.75 \\
64.44 \\
189.59\end{array}$ \\
\hline \multicolumn{2}{|l|}{ Total } & 15 & 169.58 & 116.00 \\
\hline Pore Width um (10-laundering) & $\begin{array}{l}\text { Group A } \\
\text { Group B } \\
\text { Group C }\end{array}$ & $\begin{array}{l}5 \\
5 \\
5\end{array}$ & $\begin{array}{l}137.96 \\
332.64 \\
257.52\end{array}$ & $\begin{array}{c}17.23 \\
228.15 \\
173.61\end{array}$ \\
\hline \multicolumn{2}{|l|}{ Total } & 15 & 242.70 & 174.51 \\
\hline Pore Width um (15-laundering) & $\begin{array}{l}\text { Group A } \\
\text { Group B } \\
\text { Group C }\end{array}$ & $\begin{array}{l}5 \\
5 \\
5\end{array}$ & $\begin{array}{l}151.24 \\
419.34 \\
314.40\end{array}$ & $\begin{array}{c}30.21 \\
302.89 \\
182.38\end{array}$ \\
\hline \multicolumn{2}{|l|}{ Total } & 15 & 294.99 & 221.39 \\
\hline Pore Width um (20-laundering) & $\begin{array}{l}\text { Group A } \\
\text { Group B } \\
\text { Group C }\end{array}$ & $\begin{array}{l}5 \\
5 \\
5\end{array}$ & $\begin{array}{l}165.22 \\
550.60 \\
357.86\end{array}$ & $\begin{array}{c}37.03 \\
285.54 \\
190.13\end{array}$ \\
\hline \multicolumn{2}{|l|}{ Total } & 15 & 357.89 & 246.04 \\
\hline
\end{tabular}




\begin{tabular}{|c|c|c|c|c|c|}
\hline Sample code & $\begin{array}{c}\text { Pore width um } \\
\text { New gown }\end{array}$ & $\begin{array}{c}\text { Pore width um } \\
\text { 5-L }\end{array}$ & $\begin{array}{c}\text { Pore width um } \\
10-\text { L }\end{array}$ & $\begin{array}{c}\text { Pore width um } \\
\text { 15-L }\end{array}$ & $\begin{array}{c}\text { Pore width um } \\
\text { 20-L }\end{array}$ \\
\hline AT (Ashar Textiles) & - & - & - & - & 0.5 \\
\hline
\end{tabular}

Table-III. Pore size Analysis of Experimental Surgical gown Fabric (porosity) at different Time Intervals

was significantly different or increasing trend in mean pore length size among all study groups when measured at different laundry intervals i.e. [ $p$-value (Factor) $=0.001 \& p$-value (Factor* Group) $=0.028]$

\section{Pore size analysis of Experimental surgical} gown fabric length (porosity)

Porosity of the fabric used for the surgical gown is important not only it makes the fabric comfortable and aerated but it allows pathogens and other bacteria to pass through the fabric. The size of the pore has to be optimum both in its length, width and distribution. Porosity is expected to remain optimal during the cycle or use in laundry.

For new gown pore size analysis (length) at 0 laundering it was $0 \%$, at 5th laundering Pore size analysis (length) was $0 \%$, at 10 th laundering Pore size analysis (length) $0 \%$, at 15th laundering Pore size analysis (length) $0 \%$ and at 20th laundering Pore size analysis (length) was $0.5 \%$.

The results are showing no length or width wise pores in the fabric except there are tiny holes of 0.5 after 20 launderings. The size of staphylococcus Aureus is less than $2 \mu \mathrm{m}$ in length from chains and large colonies greater than $0.5 \mathrm{~mm}$ in size. So we can say that the fabric will not let the staphylococcus Aureus pass through the fabric.

Fabrics having smaller pore size are considered to have better barrier efficacy. As a principle, the pore size of the fabric must be smaller than the size of micro-organism or its carrier. For instance, in case of blood borne bacterial infections pore size of fabric must be smaller than the size of the bacteria while it must be smaller than the size of the carrier, if carriers like dust or shed skin cells are considered3.

\section{DISCUSSION}

We compared 3 different groups (A, B, \& C) of hospitals for pore size of surgical gowns.

For the results of pore size In all groups a significant increase in pore size was observed at 0 laundering to 5 th laundering and at 10 thlaunderingto 15 thlaundering, 20thlaunderingand at 15thlaunderingto 20th laundering respectively. It is due to the reason that repeated laundering increases the pore size of the fabric. The laundering procedure and the detergent/soap being used for laundering surgical gown are also damaging the fabric. Sterilization is also one of the damaging causes. Steam helps the pores to grow large. The porosity of the fabrics increased after laundering, which indicates that the fabric had a more open structure and that microorganisms and liquids could pass through the fabric structure more easily.

For experimental gowns the fabric is not showing any pores or holes till 15th laundering but after 20th laundering there are tiny holes (approximately 0.5um) spread randomly in the fabric. This shows the compact structure of fabric weave. Leonas $(1998)^{2}$ observed that after repeated laundering the pore size of fabric increases and it allows the microorganisms to pass through the fabric more easily. Similarly, Smith and Nichols $(1991)^{10}$ studied that the fabric of reusable gowns becomes deteriorated because of repeated washing and sterilization. Moreover, McCullough (1994) ${ }^{11}$ pointed out that the surgical gowns coated or filmed showed better fluid resistance than non-coated, she further discussed that gowns should be selected according to the types of surgical procedures. Repeated laundering the tiny pores becomes bigger and let microorganism pass more easily. Water repellency rate decreases after each subsequent laundering. Large holes allow bacteria to pass 
through more easily². Leonas, concluded that the porosity of the fabrics increased after laundering, which indicates that the fabrics had a more open structure and that microorganisms and liquids could pass through the fabric structure more easily. In a case study, reusable fabrics were found to be more cost effective than disposable fabrics ${ }^{12}$.

\section{CONCLUSIONS}

The factor under consideration in this study was the pore size analysis of the existing and experimental surgical gown fabric. These surgical gowns subjected to microscopic test. The fabric used for the existing surgical gowns was not up to the mark and did show large pores under microscope. The experimental surgical gown showed no pores in the fabric structure when subjected to scanning electron microscope.

The functional ability of resistance against bacterial penetration of the surgical gowns is important because the risk of SSI. If the patient develops SSI weather it is grades 1, 2 or 3 the cost which in cures is significant while the patient is in the hospital and even after discharged home. The cost effectiveness of the existing reusable surgical gowns becomes insignificant as none of the existing surgical gowns offer any resistance against bacterial penetration and the risk of SSI with subsequent treatment cost.

Copyright@ 17 July, 2014.

\section{REFERENCES}

1. Aibibu, D., Lehmann, B., Offermann, P. Barrier effect of woven fabrics used for surgical gowns. AUTEX, 2003;186-193.

2. Leonas, K.K. Effect of laundering on the barrier properties of reusable surgical gown fabrics. Am J Infect Control, 1998;494-501.
3. Leonas,K.K. and Jinkins,R.S. The relationship of selected fabric characteristics and the barrier effectiveness of surgical gown fabric. Am J Infect Control, 1997;16-23.

4. AST. (2012). Recommended Standards of Practice for Surgical Drapes. Retrieved from - AST Recommended Standards of Practice for Surgical Drapes. (2012). O http://www.ast.org/pdf/ Standards_of_Practice/RSOP_Surgical_Drapes.pdf

5. Robertson, A.F. Air porosity of open-weave fabrics. Part I: metallic meshes. Textile Res J, 1950;838-844.

6. Umbach, K.H. . Physiological function of OR- and hospital protective clothing. FiberMed06. Finnland 2006.

7. Bartels, V. Physiologische Aspekte von OPTextillien. Frankfurt Main, Deutscher 2006.

8. Xie, S. Characterization of interyarn pore size and its distribution in plain woven fabrics. North Carolina: Graduate Faculty of North Carolina State University, Department of Textile Engineering, Chemistry, and Science, Raleigh, Master thesis 2002.

9. Lehmann, B., Offermann, P., Schnitzer, C. and Ripperger, S. Woven fabric from microfilaments for surgical gowns having a better barrier effect. Woven fabric from microfilaments for Proceedings of V International Scientific Conference, Medtex, Lodz, 2005; (pp. 15-19). Lodz,Poland.

10. Smith, J.W. and Nichols, R.L. Barrier efficiency of surgical gowns: Are we really protected from our patients' pathogens? Arch Surg, 1991; 756-763.

11. McCullough, E. A. Methods for determining the barrier efficacy of surgical gowns. AJIC Am J Infect Control, 1993;68-74.

12. DiGiiacomo,J.C., Odom,J.W., Ritota,P.C.and Swan,K.G. Cost contaminants in the operating room:Use of reusable verses disposable clothing. The American Surgeon, 1992; 654-656. 